\title{
Pendampingan UMKM di Kabupaten Karawang dalam Memaksimalkan Pemanfaatan Insentif Pajak Selama Masa Pandemi Endang Mahpudin ${ }^{*}$, Annisa Agnia ${ }^{2}$, Mineva Riskawati Vitaningrum ${ }^{3}$ 1,2,3Universitas Singaperbangsa Karawang Email: endang.mahpudin@fe.unsika.ac.id ${ }^{1}$, annisa.junia@fe.unsika.ac.id², 1710631030116@student.unsika.ac.id ${ }^{3}$ \\ *Corresponding author: endang.mahpudin@fe.unsika.ac.id ${ }^{1}$
}

\begin{abstract}
ABSTRAK
Kegiatan pengabdian ini bertujuan untuk mengedukasi Usaha Mikro, Kecil dan Menengah serta memberikan pendampingan dalam mendapatkan haknya yang berupa insentif pajak selama pandemi Covid-19 yang berada di wilayah Kabupaten Karawang. Terdapat 3 tahap dalam metode pengabdian ini. Tahap pertama adalah metode focus group discussion dan sharing time. Tahap kedua yaitu sosialisasi secara daring dengan menggunakan aplikasi berupa zoom. Tahap ketiga yaitu tahap aksi yang berupa pendampingan bagi UMKM Binaan. Berdasarkan kegiatan yang telah dilakukan UMKM Binaan mendapatkan hasil berupa surat keterangan PP 23 Final 0,5\% ditanggung pemerintah, pengisian e-form secara online serta pembukuan secara sederhana. Kegiatan pengabdian ini harus dilakukan secara terus menerus setiap tahunnya untuk menciptakan UMKM yang naik kelas serta meningkatkan kepatuhan perpajakan baik bagi para pelaku UMKM maupun masyarakat publik.
\end{abstract}

Kata Kunci: Insentif Pajak; Pengabdian; UMKM.

\section{Assistance of MSMEs in Karawang Regency in Maximizing the Utilization of Tax Incentives During the Pandemic}

\begin{abstract}
This service activity aims to educate Micro, Small, and Medium Enterprises and provide assistance in obtaining their rights in the form of tax incentives during the Covid-19 pandemic in the Karawang Regency area. I have only three stages in this method of devotion. The first stage is the focus group discussion method and time-sharing. The second stage is bold socialization using an application in the form of zoom. The third stage is the action stage in the form of mentoring-assisted MSME. Based on the Assisted MSME's activities, the results are in the form of a letter of PP 23 Final $0.5 \%$ borne by the government, filling out online forms, and simple bookkeeping. This service activity must be carried out continuously every year to create "UMKM Naik Kelas" and increase taxation for both MSME players and the public.
\end{abstract}

Kata Kunci: Tax Insentive; Service; UMKM 
Endang Mahpudin, Annisa Agnia, Mineva Riskawati Vitaningrum/Aksiologiya: Jurnal Pengabdian Kepada Masyarakat. Vol. 5, No. 4, November 2021 Hal 580-589

\section{PENDAHULUAN}

Sesuai fasalfah undangundang perpajakan, bayar pajak bukan sekadar kewajiban saja, namun merupakan bentuk wujud berpatisipasi dalam pembangunan serta pembiayaan negara (Mahpudin 2020). Perpajakan merupakan sektor yang paling besar dalam menyumbang pembangunan serta keberlangsungan ekonomi suatu negara (Rahmadhani, Cheisviyanny, and Mulyani 2020). Pemerintah Indonesia menargetkan pemasukan dari pajak tahun 2019 sebesar 1,786 Triliun (Hidayat et al. 2020). Usaha Mikro Kecil Menengah (UMKM) sedang diincar oleh pemerintah dikarenakan memiliki potensi yang bagus dalam rangka peningkatan penerimaan pajak (Ayem and Nofitasari 2019).

UMKM merupakan sektor yang turut andil dalam perekenomian nasional (Ayem and Nofitasari 2019). Jumlah UMKM dari tahun ketahun selalu mengalami kenaikan yang dapat memberikan peluang besar bagi pemerintah guna menjangkau sektor ini dalam upaya meningkatkan kepatuhan pajak yang akan menaikan penerimaan pajak (Rahmadhani et al. 2020). UMKM dari tahun 2012 hingga 2017 mengalami kenaikan hingga 13,98\% (Sari, Ratna Hindria Dyah Pita 2020).

Sejak 11 Maret 2020, WHO menyatakan Covid-19 pandemi, virus ini menginfeksi 23,3 juta orang di 210 negara dan 741.000 korban jiwa. Hingga 17 Oktober 2020 di Asia
Tenggara, kasus yang telah dikonfirmasi se-Asia Tenggara sebesar 869.515 kasus dan 21.076 kematian (Djalante 2020). Covid-19 menyebabkan perekonomian Indonesia menjadi memburuk sehingga masuk dalam fase krisis (Indaryani, Budiman, and Mulyani 2020). Pemberian insentif pajak merupakan Langkah pemerintah guna memulihkan ekonomi nasional. Kebijakan ini diambil sebagai Langkah menggerakanroda perekonomian yang tengah turun pesat (Indaryani et al. 2020). Pada PMK No. 44 Thn 2020, pemerintah menggratiskan PPh Final UMKM PP No. 23 Thn 2018 hingga Desember 2020. Bantuan berupa insentif ini diberikan kepada UMKM karena telah berjasa bagi negara dalam meningkatkan pendapatan. Adanya kebijakan insentif pajak pemerintah harus gencar melakukan sosialisasi maupun pendampingan informasi terkait PMK Nomor 44 Tahun 2020 (Ayem and Nofitasari 2019). Dalam penelitian terdahulu bahwa secara parsial sosialisasi mampu pembengaruhi kepatuhan wajib pajak (Ananda 2015).

Dilihat dari fenomena yang terjadi, maka dibuatlah artikel ini guna memberikan edukasi bagi pembaca perlunya pendampingan bagi UMKM untuk meningkatkan kepatuhan terhadap perpajakan serta menambah skill bagi para pelaku UMKM. Mengingat pentingnya keberadaan UMKM bagi penambah pemasukan negara. 


\section{METODE PENELITIAN}

Pengabdian ini dilakukan dalam tiga tahapan :

\section{Tahap Focus Group Discussion}

Melakukan pengumpulan data dan pembuatan grup menggunakan media sosial sebagai wadah berdiskusi kepada pelaku UMKM Binaan. Dengan menggunakan metode FGD dan Sharing Section diharapkan UMKM dapat lebih nyaman dalam berkomunikasi satu sama lain.

2. Tahap Sosialisasi

Menggunakan metode sosialisasi dipilih untuk memaparkan solusi yang menjadi perkara pada tahap sebelumnya. Sosialisasi dilakukan secara daring dengan menggunakan Zoom, Adapun alasannya supaya menurunkan tingkat penyebaran Covid-19. Materi yang dibahas dalam sosialisasi berupa :

a) Macam - macam insentif pajak yang diberikan

b) Bagaimana cara mendapatkan insentif pajak dan pemanfaatannya

3. Tahap Aksi

Pada tahap aksi, tim pengabdian menggunakan metode asistensi atau pendampingan. Pendampingan terhadap para pelaku UMKM memiliki tujuan untuk memaksimalkan hasil sehingga dapat meningkatkan kepatuhan karena dibimbing lebih intensif dari tim pengabdian. Sehingga hasil yang didapatkan menjadi maksimal. Adapun kegiatan ini jika dijabarkan dalam bentuk flowchart pada gambar 1.

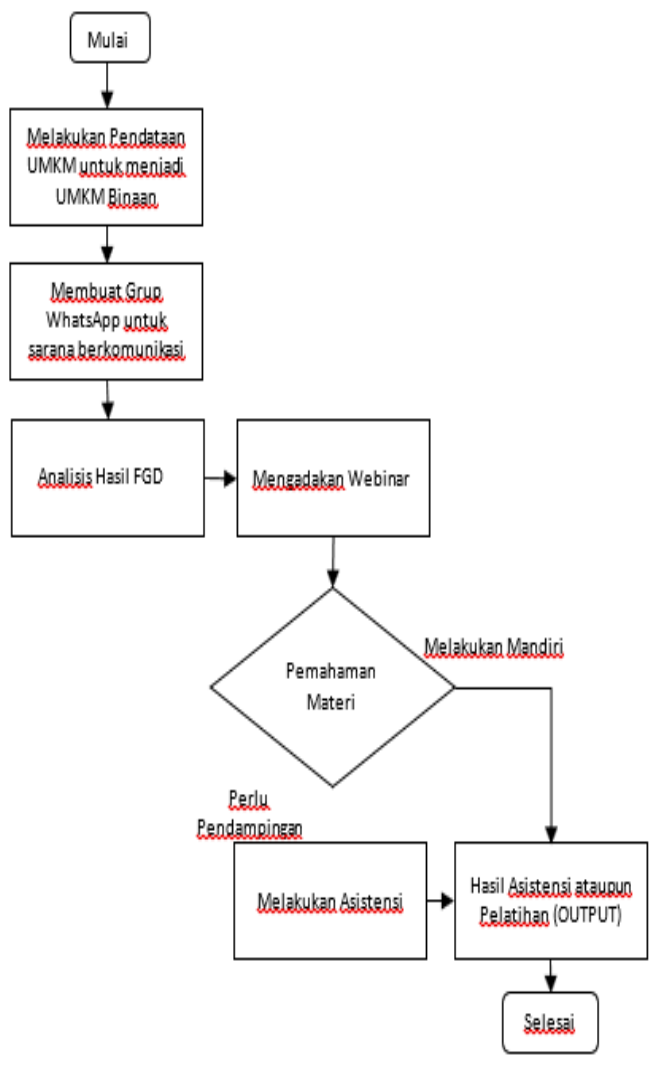

Gambar 1: Flowchart Kegiatan

Pengabdian

\section{HASIL DAN PEMBAHASAN}

Pelaksanaan program kerja pengabdian dimulai dari melakukan survei ketempat sasaran yaitu 30 kecamatan yang berada di Kabupaten Karawang. Dari hasil survei yang dilakukan didapatkan data UMKM yang bersedia sebagai UMKM Binaan berjumlah 115 sebagai smple setiap kecamatan di Kabupaten Karawang. 
Tabel 1: Data Mitra UMKM Binaan di Kabupaten Karawang

\begin{tabular}{clcl}
\hline No & \multicolumn{1}{c}{ Kecamatan } & $\begin{array}{c}\text { Jumlah } \\
\text { UMKM } \\
\text { Binaan }\end{array}$ & \\
\hline $\mathbf{1}$ & Banyusari & 2 & Kerajinan \\
\hline $\mathbf{2}$ & Batujaya & 3 & Kuliner, Fashion \\
\hline $\mathbf{3}$ & Ciampel & 2 & Kuliner \\
\hline $\mathbf{4}$ & Cibuaya & 2 & Kuliner \\
\hline $\mathbf{5}$ & Cikampek & 10 & Kerajinan, kuliner,Furniture \\
\hline $\mathbf{6}$ & Cilamaya Kulon & 3 & Catering \\
\hline $\mathbf{7}$ & Cilamaya Wetan & 2 & Makanan \\
\hline $\mathbf{8}$ & Cilebar & 2 & Kontraktor, Mekanikal, Elektrikal \\
\hline $\mathbf{9}$ & Jatisari & 3 & Online Shop Fashion \\
\hline $\mathbf{1 0}$ & Jayakerta & 3 & Kuliner \\
\hline $\mathbf{1 1}$ & Karawang Barat & 7 & Fashion, Otomotif,kuliner \\
\hline $\mathbf{1 2}$ & Karawang Timur & 5 & Kuliner, Pedagang Kelontong, Jasa B3 \\
\hline $\mathbf{1 3}$ & Klari & 9 & Makanan, Fashion, Pulsa, Kosmetik, \\
& & & furniture, budikdamber, kerajinan \\
\hline $\mathbf{1 4}$ & Kota Baru & 4 & Kuliner \\
\hline $\mathbf{1 5}$ & Kutawaluya & 3 & Furniture atau perabot rumah tangga \\
\hline $\mathbf{1 6}$ & Lemahabang & 3 & Sembako, kuliner \\
\hline $\mathbf{1 7}$ & Majalaya & 2 & Kuliner \\
\hline $\mathbf{1 8}$ & Pakisjaya & 2 & Kuliner \\
\hline $\mathbf{1 9}$ & Pangkalan & 3 & Salon, Kuliner \\
\hline $\mathbf{2 0}$ & Pedes & 2 & Kuliner \\
\hline $\mathbf{2 1}$ & Purwasari & 3 & Bengkel, Kuliner \\
\hline $\mathbf{2 2}$ & Rawamerta & 2 & Fashion \\
\hline $\mathbf{2 3}$ & Rengasdengklok & 3 & Salon, Pupuk \\
\hline $\mathbf{2 4}$ & Tegalwaru & 3 & Kuliner, Sembako \\
\hline $\mathbf{2 5}$ & Telagasari & 2 & Kuliner \\
\hline $\mathbf{2 6}$ & Telukjambe Barat & 7 & Toko kelontong, Otomotif \\
\hline $\mathbf{2 7}$ & Telukjambe Timur & 15 & Kuliner,acc HP,fashion, IT Konsultan, \\
& & 2 & pupuk,konveksi \\
\hline $\mathbf{2 8}$ & Tempuran & 3 & Kuliner \\
\hline $\mathbf{2 9}$ & Tirtajaya & 115 & Penggilingan padi, Kuliner \\
\hline $\mathbf{3 0}$ & Tirtamulya & & \\
\hline Jumlah UMKM Binaan & & \\
\hline & & & \\
\hline
\end{tabular}

Kegiatan selanjutnya yaitu pembuatan kelompok menggunakan via sosial media berupa WhatsApp, hal ini dipilih karena melihat situasi saat ini yaitu penyebaran Covid-19 yang semakin meningkat. Tujuan dari pembuatan kelompok ini sendiri digunakan sebagai sarana informasi, FGD (Focus Group Discussion), asistensi secara online dan komunikasi.

Tahapan berikutnya berupa sosialisasi tentang pemanfaatan fasilitas insentif pajak selama pandemi. Sosialisasi ini berupa seminar yang menggunakan web ataupun aplikasi meeting yang biasa kita sebut webinar. Webinar yakni 
singkatan dari kata web dan seminar.

Sosialisasi melalui webinar dipilih karena menyikapi situasi yang saat ini sedang terjadi

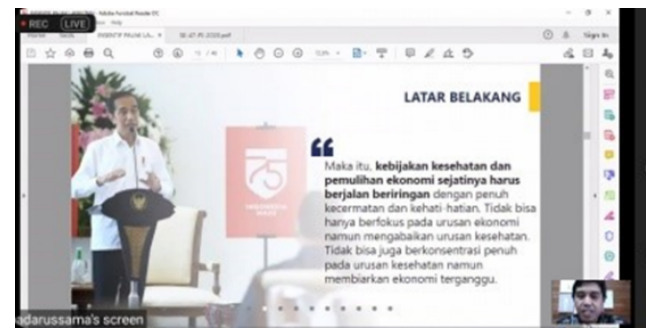

Gambar 2: Pelaksanaan Webinar 1 dengan judul "Strategi Kebijakan Perpajakan Di Masa Pandemi Covid - 19"

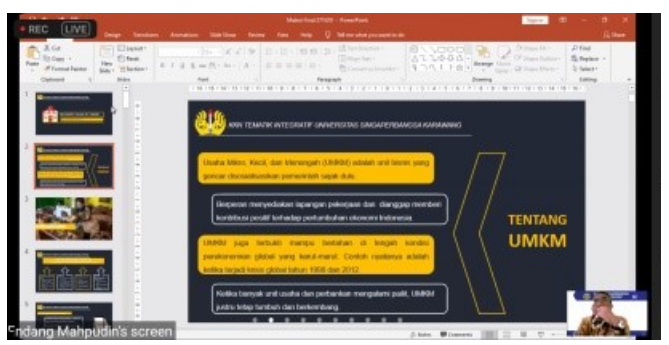

Gambar 3: Pelaksanaan Webinar 2 dengan judul "Dukungan Pajak dimasa Sulit"

Webinar dijadikan sebagai alat atau sarana penyaluran informasi serta sosialisasi singkat sebelum dilakukannya asistensi jika responden atau partisipan belum memahami materi yang telah disampaikan. Tetapi tidak menutup kemungkinan jika semua partisipan membutuhkan asistensi supaya lebih memahami betul isi dari materi tersebut.
Tahap terakhir yaitu asistensi atau pendampingan. Asistensi diperlukan guna partisipan dapat berinteraksi bebas sehingga berpengaruh terhadap kualitas hasil. Untuk membantu partisipan dalam melakukan tugasnya selaku wajib pajak UMKM diperlukannya asistensi terhadap UMKM Binaan yang menjadi mitra. Dengan dilakukannya asistensi diharapkan hasil yang didapatkan menjadi maksimal.

Kegiatan asistensi juga lebih mempermudah wajib pajak berkoordinasi dan menanyakan hal yang belum mereka ketahui. Sebelum melakukan asistensi para mentor atau yang mengasistensikan melakukan TOT (Training of Trainer) terlebih dahulu supaya ilmu yang mereka sampaikan sama dan sesuai dengan dengan apa yang ditargetkan. Asistensi dibagi beberapa kelompok hal tersebut dilakukan supaya pelaksanaan lebih fokus dan hasil dapat tercapai. Materi yang dipandu pada saat asistensi berupa insentif pajak yang diberikan pemerintah sebagai dukungan pada masa sulit ini serta materi tambahan berupa pembukuan sederhana, pembuatan laporan pajak dengan online platform, cara bayar pajak menggunakan online platform dan melaporkan pajak dengan online platform. Berikut tabel dari hasil program pengabdian : 
Tabel 2: Data Mitra UMKM Binaan di Kabupaten Karawang

\begin{tabular}{|c|c|c|c|c|c|}
\hline \multirow[b]{2}{*}{ No } & \multirow{2}{*}{$\begin{array}{l}\text { Pelatihan } / \mathrm{Pr} \\
\text { ogram yg } \\
\text { diberikan }\end{array}$} & \multirow{2}{*}{$\begin{array}{l}\text { Tujuan } \\
\text { Pelatihan/Program }\end{array}$} & \multirow{2}{*}{$\begin{array}{l}\text { Tempat } \\
\text { Pelaksan } \\
\text { aan }\end{array}$} & \multicolumn{2}{|r|}{ Hasil } \\
\hline & & & & $\begin{array}{l}\text { Sebelum } \\
\text { Pelatihan }\end{array}$ & Sesudah Pelatihan \\
\hline 1 & $\begin{array}{l}\text { Sharing } \\
\text { Time dan } \\
\text { FGD }\end{array}$ & $\begin{array}{l}\text { Mengetahui kendala } \\
\text { kendala yg dilakukan } \\
\text { pada saat covid-19 } \\
\text { serta berdiskusi untuk } \\
\text { mencari solusi } \\
\text { (Permasalahan dalam } \\
\text { bidang ekonomi) }\end{array}$ & $\begin{array}{l}\text { Whats Ap } \\
p \text { Group }\end{array}$ & $\begin{array}{l}\text { Belum dapat } \\
\text { memecahkan } \\
\text { masalah } \\
\text { karena } \\
\text { belum } \\
\text { menemukan } \\
\text { solusi yg } \\
\text { terbaik }\end{array}$ & 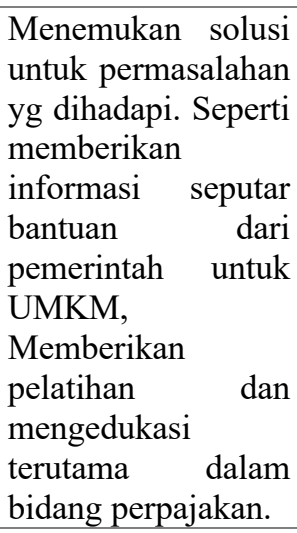 \\
\hline 2 & $\begin{array}{l}\text { Webinar } \\
\text { "Strategi } \\
\text { Kebijakan } \\
\text { Perpajakan } \\
\text { di Masa } \\
\text { Pandemi } \\
\text { Covid-19" }\end{array}$ & $\begin{array}{l}\text { Sosialisasi mengenai } \\
\text { insentif pajak yang } \\
\text { diberikan pemerintah } \\
\text { pada masa pandemi } \\
\text { covid }\end{array}$ & $\begin{array}{l}\text { Via } \\
\text { Zoom } \\
\text { Meeting }\end{array}$ & $\begin{array}{l}\text { Belum } \\
\text { mengetahui } \\
\text { tentang } \\
\text { insentif } \\
\text { pajak }\end{array}$ & $\begin{array}{l}\text { Mengetahui jenis- } \\
\text { jenis insentif pajak } \\
\text { yang diberikan }\end{array}$ \\
\hline 3 & $\begin{array}{l}\text { Webinar } \\
\text { "Dukungan } \\
\text { Pajak } \\
\text { dimasa } \\
\text { Sulit" }\end{array}$ & $\begin{array}{lr}\text { Sebagai } & \text { sarana } \\
\text { membantu UMKM } \\
\text { untuk mendapatkan } \\
\text { Info seputar UMKM } \\
\text { yang update }\end{array}$ & $\begin{array}{l}\text { Via } \\
\text { Zoom } \\
\text { Meeting }\end{array}$ & $\begin{array}{l}\text { Belum } \\
\text { mengetahui } \\
\text { Insentif } \\
\text { pajak dll }\end{array}$ & $\begin{array}{l}\text { Memiliki Insentif } \\
\text { Pajak, NPWP serta } \\
\text { menambah Ilmu }\end{array}$ \\
\hline 4 & $\begin{array}{l}\text { Upload } \\
\text { informasi } \\
\text { seputar } \\
\text { perpajakan } \\
\text { mengenai } \\
\text { UMKM } \\
\end{array}$ & $\begin{array}{l}\text { Sarana publik untuk } \\
\text { sharing informasi } \\
\text { seputar perpajakan }\end{array}$ & $\begin{array}{l}\text { Social } \\
\text { Media } \\
\text { (WhatsA } \\
\text { pp dan } \\
\text { Instagra } \\
\text { m) }\end{array}$ & $\begin{array}{l}\text { Kurang } \\
\text { memahami } \\
\text { Informasi } \\
\text { seputar } \\
\text { Perpajakan }\end{array}$ & $\begin{array}{l}\text { Mengetahui } \\
\text { Informasi seputar } \\
\text { tentang Perpajakan }\end{array}$ \\
\hline 5 & $\begin{array}{l}\text { Pendampin } \\
\text { gan untuk } \\
\text { mendapatka } \\
n \text { insentif } \\
\text { pajak }\end{array}$ & $\begin{array}{l}\text { Mendapatkan Surat } \\
\text { Ketetapan bagi } \\
\text { UMKM perihal PP } 23 \\
\text { PPh Final 0,5\% DTP }\end{array}$ & $\begin{array}{l}\text { WhatsAp } \\
\text { p Group }\end{array}$ & $\begin{array}{l}\text { Tidak } \\
\text { mengerti } \\
\text { bagaimana } \\
\text { caranya } \\
\text { mendapatka } \\
\mathrm{n} \quad \text { insentif } \\
\text { pajak }\end{array}$ & $\begin{array}{l}\text { Berhasil } \\
\text { mendapatkan Surat } \\
\text { Ketetapan bagi } \\
\text { UMKM perihal PP } \\
23 \text { PPh Final } 0,5 \% \\
\text { DTP }\end{array}$ \\
\hline 6 & $\begin{array}{l}\text { Pendampin } \\
\text { gan } \\
\text { pembukuan } \\
\text { sederhana } \\
\text { dan } \\
\text { pengisian E- } \\
\text { Form secara } \\
\text { online }\end{array}$ & $\begin{array}{l}\text { Supaya lebih paham } \\
\text { terhadap pembukuan } \\
\text { sederhana } \\
\text { Pengisian E-Foirm } \\
\text { secara elektronik }\end{array}$ & $\begin{array}{l}\text { Whats } A p \\
p \text { Group }\end{array}$ & $\begin{array}{l}\text { Belum } \\
\text { mengetahui } \\
\text { pembukuan } \\
\text { sederhana } \\
\text { dan } \\
\text { Pengisian E- } \\
\text { Foirm secara } \\
\text { elektronik }\end{array}$ & $\begin{array}{l}\text { Dapat membuat } \\
\text { laporan keuangan } \\
\text { secara sederhana, } \\
\text { dapat mengisi E- } \\
\text { Foirm secara } \\
\text { elektronik }\end{array}$ \\
\hline
\end{tabular}

Ditemukan beberapa aspek upaya pengembangan UMKM permasalahan yang mendasar dalam khususnya dalam perpajakan 
(Perguna, Imamul Huda Al Siddiq, and Irawan 2019) Kegiatan pengabdian ini didasari oleh permasalah yang telah ditemukan dari hasil observasi dan FGD yang telah dilakukan. Berdasarkan hasil observasi dan FGD ditemukan bahwa UMKM Binaan kurang mengerti tentang insentif pajak yang diberikan oleh pemerintah. Bahwa dapat diketahui 52,9 juta pelaku UMKM mengalami keterpurukan (Budiman 2018). Maka tim pengabdian memutuskan untuk melakukannya sosialisasi berupa materi cara memperoleh insentif pajak serta melakukan pendampingan.

Pemahaman pajak yang baik dari sosialisasi diharapkan wajib pajak taat akan kewajibannya (Maharani, Sari 2019). Serta terdapat penelitian bahwa Kepatuhan wajib pajak dapat dipengaruhi oleh sosialisasi (Nurvita 2013). Dalam pelaksanaan sosialisasi dibahas mengenai macam-macam insentif yang dikeluarkan oleh pemerintah sesuai dengan PMK. 44 tahun 2020. Kemudian bagaimana cara memperoleh insentif dan diberikan tutorialnya dalam bentuk slide power point.

Kegiatan selanjutnya yaitu pendampingan bagi UMKM Binaan yang merupakan tahap aksi dari hasil sosialisasi. Jadi tujuannya dilakukan pendampingan untuk memastikan UMKM Binaan dapat mengetahui cara mendapatkan insentif pajak. Dan juga sebagai alat ukur untuk menentukan tingkat kemajuan dari
UMKM Binaan. Hasil dari pelaksanaan pengabdian ini dapat diukur dari tingkat pemahaman UMKM Binaan yang berhasil memperoleh insentif pajak selama masa pandemic serta pemahaman melakukan proses pelaporan pajak .

Adapun runtutan kegiatan pengabdian sebagai berikut :

1. Survei untuk mencari yang bersedia menjadi UMKM Binaan dilakukan pada tanggal 20 September - 3 Oktober 2020

2. Melakukan FGD dan Sharing time di grup Whats App UMKM Binaan. FGD dipimpin oleh 1 moderator dan 1 notulensi untuk memberi kesimpulan. Pelaksanaan kegitaan tanggal 4 Oktober 2020 pukul 8 pagi hingga 4 sore.

3. Kegiatan selanjutnya yaitu sosialisasi yang dilakukan sebanyak 2 kali. Untuk sosialisasi pertama dibuka untuk umum dan tidak lupa UMKM Binaan ,jadi peserta dari webinar yang pertama tidak hanya UMKM Binaan tetapi juga mahasiswa yang tersebar di Jabodetabek jadi pada sosialisasi pertama total peserta sebanyak 650 Peserta dengan rincian 115 UMKM Binaan dan 535 mahasiswa. Pada webinar 1 dilaksanakan pada tanggal 11 Oktober 2020 dari jam 09.00 12.30 WIB. Kemudian untuk sosialisasi kedua dikhususkan untuk UMKM Binaan dengan isi materi yang lebih di khususkan untuk UMKM berupa penjelasan insentif pajak dan tahapan 
mendapatkannya serta materi tambahan berupa pembukuan sederhana dan pelaporan. Kegiatan ini dilaksanakan pada tanggal 27 Oktober 2020 jam 9 pagi hingga 1 siang.

4. Asistensi atau pendamping merupakan program pengabdian terakhir. Materi inti pada saat pendampingan berupa Langkah mendapatkan insentif pajak berupa surat Peraturan Pemerintah Nomor $23 \mathrm{PPh}$ Final $0,5 \%$ di Tanggung Pemerintah yang dikeluarkan oleh Direktorat Jenderal Pajak. Selain materi inti tim pengabdian juga memberikan materi tambahan berupa materi penunjang seperti pembukuan sederhana dan cara mengisi e-form secara online. Kegiatan pendampingan atau asistensi dimulai pada tanggal 1 November 2020 untuk materi inti dan tanggal 7 November 2020 untuk materi tambahan. Kegiatan dilaksanakan pukul $09.00-21.00$ WIB dengan catatan tujuan atau hasil tercapai walaupun dengan waktu yang fleksibel.

5. Selain itu tim pengabdian juga mengedukasi melalui sosial media berupa Instagram dan WhatsApp. Tujuan dari program ini untuk mengedukasi masyarakat publik khususnya kalangan millenial yang biasanya menggunakan sosial media.

\section{SIMPULAN}

Kegiatan pengabdian ini guna memberikan edukasi dan pendampingan dalam upaya mendapatkan haknya selaku wajib pajak berupa insentif pajak selama pandemic Covid-19. Kegiatan ini bersubjekan para pelaku UMKM yang tim pengabdian pilih menjadi UMKM Binaan di wilayah Kabupaten Karawang. Kegiatan pengabdian kepada masyarakat ini dilakukan secara semi daring karena menimalisir penyebaran Covid-19 yang semakin meningkat terlebih khusus di daerah Karawang. Adapun 3 tahapan dalam kegiatan ini yaitu tahap FGD atau sharing time, tahap sosialisasi, dan tahap aksi yaitu berupa pendampingan. Meskipun pendampingan dalam bentuk semi daring tidak mengurangi hasil ataupun tujuan dari pengabdian ini.

Pada dasarnya kegiatan pengabdian ini, UMKM menjadi subjek penting dalam kegiatan pengabdian yang dilakukan dikalangan perguruan tinggi khususnya kegiatan yang terkait dengan sosialisasi dan pendampingan perpajakan. Keterbatasan pengetahuan menjadikan salah satu kendala dalam berkembangnya UMKM. Dengan memberikan pengabdian ini diharapkan dapat meningkatkan pengetahuan bagi UMKM Binaan serta kepatuhan pajak bagi para pelaku UMKM. 


\section{DAFTAR PUSTAKA}

Ananda, Pasca Rizki Dwi. 2015. "Pengaruh Sosialisasi Perpajakan, Tarif Pajak, Dan Pemahaman Perpajakan Terhadap Kepatuhan Wajib Pajak (Studi Pada UMKM Yang Terdaftar Sebagai Wajib Pajak Di Kantor Pelayanan Pajak Pratama Batu)." Jurnal Perpajakan (JEJAK) 6(2):3955. doi:

10.1377/hlthaff.2013.0625.

Ayem, Sri, and Devi Nofitasari. 2019. "Pengaruh Sosialisasi PP No . 23 Tahun 2018 , Modernisasi Sistem Administrasi Perpajakan , Dan Biaya Kepatuhan Terhadap Kemauan Membayar Pajak Pada Wajib Pajak UMKM." Jurnal Akuntansi Dan Governance Andalas 2(2):10521.

Budiman, Nita Andriyani. 2018. "Kepatuhan Pajak Umkm Di Kabupaten Kudus." Jurnal Profita 11(2):218. doi: 10.22441/profita.2018.v11.02.0 05.

Djalante, R. et. al. 2020. "COVID-19 and ASEAN Responses: Comparative Policy Analysis." Progres in Disaster Science 8 (2020) 100129.

Hidayat, Muhammad, Lukluk Fuadah, Sri Maryati, Nur Khamisah, and Ruth Samantha Hamzah. 2020. "Pendampingan Pengelolaan Pajak Bagi Umkm Di Kota Palembang." Jurnal Abdimas Mandiri 4(1):50-54. doi: 10.36982/jam.v4i1.1045.

Indaryani, Mamik, Nita Andriyani Budiman, and Sri Mulyani. 2020. "Dampak Covid-19 Dan
Pemanfaatan Insentif Pajak

Terhadap Keberlangsungan Usaha Pada UMKM Tenun Troso Jepara." Jurnal Manajemen Dan Keuangan 9(3):276-85.

Maharani, Sari, Farida Titik Kristanti dan Kurnia. 2019. "Pengaruh Sosialisasi Perpajakan, Kualitas Pelayanan Perpajakan, Tarif Pajak, Dan Ketegasan Sanksi Perpajakan Terhadap Kepatuhan Wajib Pajak (Studi Empiris Pada Usaha Mikro Kecil Menengah Yang Terdaftar Sebagai Wajib Pajak Orang Pribadi Di Kantor Pelayanan." E-Proceeding of Management 6(ISSN : 35933601).

Mahpudin, $\quad 2020$. PERPAJAKAN. $1 \mathrm{st}$ ed. Karawang: Putra Galuh Publisher.

Nurvita, Mutia. 2013. "Pengaruh Persepsi Pengetahuan Dan Pemahaman, Sosialisasi Perpajakan, Kondisi Keuangan, Dan Ketegasan Sanksi Perpajakan Terhadap Kepatuhan Wajib Pajak Berdasarkan Peraturan Pemerintah No.46 Tahun 2013 (Studi Kasus Atas Wajib Pajak Pemilik UKM Pada KPP Prat." (46).

Perguna, Luhung Achmad, Imamul Huda Al Siddiq, and Irawan. 2019. "Desa Membangun UMKM: Pendampingan UMKM Berbasis Village Driven Development Dalam Penguatan Ekonomi Warga Di Desa Gogodeso Kabupaten Blitar." Engagement: Jurnal Pengabdian Kepada Masyarakat 3(2):217-30. doi: 10.29062/engagement.v3i2.62.

Rahmadhani, Sri Rahayu, Charoline 
Endang Mahpudin, Annisa Agnia, Mineva Riskawati Vitaningrum/Aksiologiya: Jurnal Pengabdian Kepada Masyarakat. Vol. 5, No. 4, November 2021 Hal 580-589

Cheisviyanny, and Erly Mulyani. 2020. "Analisis Kepatuhan Pajak Pelaku Umkm Pasca Penerbitan Peraturan Pemerintah Nomor 23 Tahun 2018." ISSN : 2656-3649, Vol. 2, No 1, Seri E, Februari 2020 2(1):2537-53.

Sari, Ratna Hindria Dyah Pita, Dkk. 2020. "Sosialisasi Insentif Pajak Bagi Pelaku Umkm Sebagai Dampak Pandemi Covid-19 Di Kecamatan Ciracas Jakarta Timur." P. 14 in Prosiding Seminar Nasional Administrasi Bisnis Pengabdian Masyarakat (SINABIS). The Higher Education Press. 